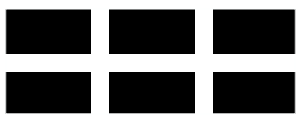

THE WILLIAM DAVIDSON INSTITUTE AT THE UNIVERSITY OF MICHIGAN BUSINESS SCHOOL

\title{
Labor Market Flexibility in Central and East Europe
}

\author{
By: Jan Svejnar
}

William Davidson Working Paper Number 496

August 2002 


\title{
Labor Market Flexibility in Central and East Europe
}

\author{
Jan Svejnar*
}

March 2002

Revised August 2002

\begin{abstract}
I explore the extent to which insufficient labor market flexibility is an important factor causing Central and East European (CEE) economies to perform worse than they could and hence slowing down their readiness to enter the European Union. My conclusion is that labor market flexibility is an issue but that it is not a major factor in comparison to imperfections and regulations in other areas such as the housing market, transportation infrastructure, capital market, corporate governance, legal framework, and business environment. In particular, my assessment is that transition labor markets have been as flexible and functional as labor markets in the market economies and that the observed differences across transitional labor markets do not account for cross-country differences in economic performance.
\end{abstract}

JEL Classification Codes: J3, J4, J5, J6, P2, P3

* The William Davidson Institute at the University of Michigan Business School, Department of Economics at the University of Michigan, and CERGE-EI, Prague. The paper greatly benefited from comments provided by participants of the CASE Conference "Beyond Transition," Warsaw, April 12-13, 2002. I would also like to thank Cristina Negrut for her valuable assistance with preparing the tables and figures for this paper. While writing the paper, I was supported by the National Science Foundation Grant No. SES 0111783, ACE grant P98-1129-R and ACE grant P98-1008-R. 


\section{Non-technical Summary}

Since 1989, most transition economies have experienced a period of sharp economic decline followed by slower than expected economic growth, a rise of the unemployment rate from zero to double digits, and appearance of a high share of long-term unemployed. These developments have naturally raised concerns that insufficient labor market flexibility is an important factor causing these economic problems and that it is slowing down the readiness of the Central and East European (CEE) economies to enter the European Union. My conclusion, based on the evidence reviewed in this paper, is that labor market flexibility is an issue but that it is not a major factor in comparison to imperfections and regulations in other areas such as the housing market, transportation infrastructure, capital market, corporate governance, legal framework, and business environment. In particular, my assessment is that transition labor markets have been as flexible and functional as labor markets in the market economies and that the observed differences across transitional labor markets do not account for cross-country differences in economic performance. My conclusion is based on the following findings:

1. The extent and effects of employment protection, labor market policies and unionization in the transition economies are similar to OECD and EU averages, and on some measures they resemble OECD economies with the most flexible labor markets.

2. The transition economies with the least regulated and institutionally least rigid labor markets have not been uniformly the fastest growing ones and vice versa. 
3. The firms in CEE economies quickly resembled their western counterparts in the extent to which they started adjusting employment in response to changes in wages and output demand.

4. Substantial labor mobility took place from the old to the new firms, with some countries transferring over one-half of the labor force within four to five years.

5. Labor mobility appears to have been rational in that it has involved both quits and layoffs, with the resulting wage gains being higher on average for the quitters than the displaced workers. Workers have reacted to labor demand shocks by traditional as well as less-traditional (in the western context) responses, including massive occupational mobility. Hence, where a carpenter in the US might react to losing a job by finding a job elsewhere as a carpenter, a laid off Russian nuclear physicist might stay in his city and look for a job as a banker.

6. The return to education and other forms of human capital have risen substantially and wages began to play an equilibrating role in the labor market.

From the policy standpoint, there are several important findings. First, the generosity of unemployment benefits has been found to have only modest negative effect on efficiency in terms of extending unemployment spells. This provides policy makers with latitude in setting the parameters of the compensation system so as to ensure popular support for the completion of the transition process. Second, economies with high unemployment tend to have fewer vacancies and estimated parameters that show lower efficiency of matching between the unemployed and vacancies and lower probability (hazard) of the unemployed leaving unemployment for employment. The lack of 
vacancies points to low demand as a cause of unemployment, while the matching and hazard estimates suggest that these economies suffer from structural issues such as skill mismatch, inferior functioning of labor market institutions and active labor market policies, and less flexible behavior of employers and workers. Third, there are indications that wages are not set completely by market forces because they vary with firms' profitability. This in turn suggests that worker-insiders raise wages at the expense of greater employment, which in turn contributes to the unemployment problem.

The above findings suggest that the principal reasons for the rapid but uneven rise in unemployment and the share of long-term unemployed in transition economies in the 1990s were (a) the enormous extent of transition-related restructuring, with labor demand falling dramatically in existing firms, (b) a major skill mismatch that took varying periods of time to alleviate, and (c) varying degrees of imperfections and regulations in other areas such as the housing markets, transportation infrastructure, capital markets, corporate governance, legal framework, and business environment.

The outstanding issue, however, is why there has been a significant resurgence of unemployment in some of the growing economies (Bulgaria, Poland, and Slovakia) but not in others in the very late 1990s and early 2000s. These are presumably not brought about by sudden bouts of transition-related restructuring, skill mismatch and newly created imperfections outside of the labor market. Demographic forces (especially a recent baby boom-let) account for some of these developments, but further research is needed to clarify this issue. 


\section{Introduction}

The fall of communism created expectations that the centrally planned economies would generate rapid economic growth and gradually catch up with middle income developed countries as they moved to a market system. Yet, the relative performance of the transition economies since 1989 has fallen short of expectations for three principal reasons: advanced western economies did unusually well in the 1990s; the economic problems associated with the transition were underestimated; and policymakers made a number of errors. The question therefore arises as to what has worked and what could have been and still could be done better.

In this paper I provide an assessment of the extent to which labor market institutions and regulations in Central and East European (CEE) economies have contributed positively or negatively to economic performance since 1989 . An understanding of the role played by the labor markets in the CEE countries, apart from being of interest per se, is important for at least four reasons. First, at a fundamental level an analysis of the functioning of nascent labor markets provides clues about the functioning of one of the basic pillars of a market system. The transition provides an interesting laboratory, with tremendous variation in key variables, as exemplified for instance by the rise of unemployment rates rose from zero to double digits in most CEE economies and the sizable declines in wages and employment in firms during the first years of the transition. Analyses of the labor market are hence able to capture the "big bang” effect of introducing a market system. From the policy standpoint a particularly important issue is why the unemployment rate rose fast in the early 1990 s in some but not all countries, and why it recently stabilized in the single digit range in some CEE 
countries (e.g., the Czech Republic, Estonia, Hungary, and Slovenia), but rose to the 15$20 \%$ range in others (e.g., Bulgaria, Poland and Slovakia). It is notable that the significant rise in unemployment in the CEE countries in the early 1990s occurred despite major declines in labor force participation, competitive devaluation of the currencies, reductions in formerly generous unemployment benefits, and introduction of active labor market policies.

Second, there is an important political consideration since voters' response to high unemployment has been quite negative in all the CEE countries. The discontent reflects anxiety that reforms require economic sacrifices without ensuring adequate social security. A major policy question therefore arises as to how the transition economies can strike a balance between (i) reducing further government intervention and completing the establishment of market incentives, and (ii) providing an adequate social safety net that ensures public support for these policies.

Third, in the context of accession to the European Union, the policy debate has by and large moved from macro stabilization (which continues to be essential but requires standard policies) to microeconomic issues such as the rate of creation of new firms, corporate governance in existing firms, enforcement of a market-friendly legal framework, enhancing the functioning of a flexible labor market, and attracting foreign direct investment. A significant emphasis has been placed on the link between unemployment and the wage and employment setting in the newly created firms, privatized versus state owned firms, and foreign owned firms. Labor market analyses may be particularly useful in providing policy guidance in this area. 
Fourth, the economies of Central and East Europe were the first ones to launch the transition process and they differed from one another in their initial conditions, policies and outcomes. The results of studies dealing with these economies therefore provide useful information for the policy makers in the economies that started transition later. $^{1}$

The initial labor market conditions varied across the CEE countries. While it was functioning, the Soviet-type economic system was characterized by full employment of labor (zero open unemployment) and centrally set wages, prices and output targets for state-owned enterprises. Income distribution was maintained at relatively egalitarian levels, most people were required to work and enterprises were allocated funds to provide the needed jobs. Starting in the 1960s, however, many CEE countries experienced slowdowns in economic growth and, as a result of popular pressure, the system started undergoing reforms. Full employment at centrally set (and low) wages was maintained but in many countries the requirement to work (e.g., for housewives) was not fully enforced. Rather than merely soliciting information and imposing targets, central planners increasingly engaged in bargaining with enterprise managers about plan targets, employment levels and financial allocations. Firms increasingly operated under soft budget constraints, being able to receive bailouts from the central authorities when producing losses. Moreover, firms could increasingly trade with one another outside of the scope of the central plan and in some countries, e.g., Poland and Hungary, workers

\footnotetext{
${ }^{1}$ Poland and Hungary for instance entered the transition with a significant private sector in agriculture and services and limited government control over enterprises. In contrast, the Czech and Slovak economies were highly centralized and almost completely state-owned. Yet, the Czech Republic and to a lesser extent Slovakia have carried out massive privatization of state property, while others, such as Bulgaria, Poland, and Romania, have been slower in privatizing their state sector. Some, such as the Czech Republic, have pushed through massive privatization, leaving the restructuring of firms for later. Others have stressed more
} 
and managers seized a significant degree of control over enterprises from the planners. By the time of the fall of the Berlin wall in 1989, the system was rapidly disintegrating in countries such as Poland and Hungary, but it still remained fairly intact in East Germany and Czechoslovakia.

The economic strategy during the transition consisted of what I have called Type I and Type II reforms (Svejnar, 2002). Type I reforms were launched rapidly in all the transition economies and they focused on the removal of the authoritarian state and introduction of basic policies aimed at softening up the impact of the transition. At the micro level, the goal of Type I reforms was to move towards the liberalization of prices, reduction of direct subsidies to trusts and state-owned enterprises, allowing trusts and firms to restructure or even break up, removing barriers to the creation of new firms and banks, carrying out small scale privatizations, and introducing a new social safety net. These reforms caused a sizable reallocation of labor away from the state-run firms, some of which went to the new private firms and some of which ended up in nonemployment.

Type II reforms have emphasized the creation of a reliable state apparatus that would provide a level playing field for the market economy and enhance its functioning. They have been more fundamental than Type I reforms and the extent of their implementation has varied across the transition economies. These reforms have involved the development of new laws, regulations and institutions that would ensure a successful market-oriented economy. They have included the in-depth development of labor market regulations and institutions related to industrial and labor relations, unemployment compensation and retirement systems, privatization of large and medium-sized

\footnotetext{
the commercialization of existing state enterprises (e.g., Poland), reorientation of exports from east to west, attracting western capital (Hungary), and creating new firms.
} 
enterprises; establishment and enforcement of a market-oriented legal system and accompanying institutions; further in-depth development of a viable commercial banking sector and the appropriate regulatory infrastructure, and assistance for the creation and growth of new firms.

The nature and extent of Type II reforms that have been carried out in different economies should, along with differences in initial conditions and exogenous shocks, provide the possibility to explain differences in economic performance across the transition countries. Note that the four leading transition economies shown in Figure 1 -Poland, Slovenia, Hungary, and Slovakia -- have pursued a relatively complete set of reforms, including maintaining relatively clear property rights and corporate governance. The Czech Republic belongs to the leading group but it underestimated the importance of the latter two sets of reforms and was the only economy in Central Europe to suffer a recession in the second half of the 1990s. Reforms in other countries have been more limited. $^{2}$

In the next section, I discuss the principal differences in the institutional and regulatory framework in the transitional labor markets and examine the extent to which they provide an explanation of relative economic performance of the CEE countries.

\footnotetext{
${ }^{2}$ For example, Hungary and to a lesser extent Slovakia privatized most state-owned enterprises in a way that assigned clear property rights. Poland and Slovenia proceeded slower, but both countries exposed the state-owned enterprises to competition and a risk of financial failure. In all four economies there was also substantial creation of new private firms that contributed to growth. The Czech Republic is notable because it was similar to the four leading economies but it neglected the need to establish a functioning legal framework and corporate governance. The privatization experience of the Czech Republic, Russia and
} 


\section{Institutions and Regulation in the Transition Labor Markets}

The transition countries have differed considerably in the nature and speed of the development of labor and social regulations and institutions and the differences have been substantial even within clusters such the CEE countries.

\section{Employment Protection}

Building on their existing legislation and using the assistance provided by the International Labour Office (ILO) and the European Union (EU), the transition economies established various forms of employment protection legislation in the 1990s. By the end of the 1990s, the CEE candidates for admission to the EU have developed a set of labor market institutions and regulations that broadly resemble those found in the EU countries (Riboud, Sanchez-Paramo and Silva-Jauregui, 2001). The CEE countries in fact fall in the middle of the EU-based flexibility index used by Riboud et al. (2001) - the index takes on values of 1 to 6 , with higher values corresponding to stricter employment protection legislation. They have therefore adopted employment protection legislation that is less flexible than those found for instance in the United Kingdom and Ireland, but more flexible than those found in the southern countries of the EU.

As in the EU, however, there are important differences across the CEE countries in terms of the exact nature and extent of employment protection. Riboud et al. (2001) show that in the late 1990s rules for hiring and firing of permanent workers (including notification requirements and severance payments) as well as rules related to collective dismissals were more flexible in Hungary and Poland than in the Czech Republic, Estonia, Slovakia and Slovenia. Legislation related to temporary employment was in turn much more

Ukraine suggests that mass privatization in the absence of a functioning legal system has negative effects on performance. 
flexible in the Czech Republic and Hungary than in Estonia, Poland, Slovakia and Slovenia. Overall, among 26 OECD and CEE countries classified by Riboud et al. (2001), the leading six EU candidate countries in CEE hold the following ranks and value of the employment protection index, respectively: Hungary $(9 ; 1.7)$, Poland $(10 ; 2.0)$, Czech Republic $(11 ; 2.1)$, Slovakia (16; 2.4), Estonia (18; 2.6), and Slovenia $(25 ; 3.5)$.

In terms of analytical and policy implications, if employment flexibility matters for a country's economic performance, we should observe better economic performance, ceteris paribus, in Hungary, Poland and Czech Republic than in Slovakia, Estonia and especially Slovenia. Yet, as may be seen from Figure 1, the labor market flexibility ranking of countries does not coincide with their ranking in terms of GDP growth during the 1990s, with Slovenia being the second fastest growing economy and the Czech Republic the slowest one. Other factors than labor market flexibility obviously affect the rate of growth of GDP, but the lack of a tight relationship with labor market flexibility is notable.

\section{Passive Labor Market Policies for the Unemployed}

Already by the end of 1991, all the CEE countries developed relatively wellfunctioning unemployment compensation and social security benefit schemes (principal pillars of their passive labor market policies). As they struggled to strike a balance between providing an adequate social safety net and reducing government intervention, while controlling budget deficits, CEE governments gradually reduced the level of protection in unemployment (Ham, Svejnar and Terrell, 1998). In particular, already by 1992-93 all the CEE countries required an individual to have a minimum period of previous employment in order to be eligible to collect unemployment compensation. Moreover, in all 
of the CEE countries, except Albania, the level of unemployment benefits was based on fixed replacement rates of previous wages and, except for Bulgaria and Poland; these replacement rates fell over the entitlement period. All the CEE countries, except Poland, also imposed a low maximum level of benefits (between 1.4 and 2.0 times the minimum wage). Finally, there was no indexation of benefits for inflation in any of the CEEs.

As was the case with employment protection, by the late 1990s the nature of passive and active labor market policies of the EU candidates started resembling policies pursued in the EU and diversity occurred across countries. Riboud et al. (2001) show that the replacement ratio (ratio of unemployment benefits to previous wage) is very low in Estonia (about 10\%), relatively low in Poland (40\%) and somewhat low in the Czech Republic (50\%). In Hungary (64\%), Slovakia (60\%) and Slovenia (63\%) the replacement ratio resembles the EU average of $60 \%$. The duration of unemployment benefits in months is only 3-6 in Estonia and 6 in the Czech Republic. It rises to 6-12 in Slovakia, 12 in Hungary, 2-24 in Slovenia, and full 12-24 in Poland. These figures compare to 6 months in the United States, 12 month in the UK, 24 months in Spain and no limit in Belgium. The coverage rate (percentage of unemployed receiving unemployment benefits), which proxies for eligibility, also shows striking differences across countries, with the rate having been stable in the 1990s at about 40-50\% in the Czech Republic and Estonia, and at $70-75 \%$ in Hungary. In contrast, the coverage rate has fallen continuously in the 1990s from 80 to $20 \%$ in Poland and Slovakia and from 40 to $30 \%$ in Slovenia. Except for Poland, the CEE countries spend a much smaller share of GDP on unemployment compensation (passive policies) than the EU and OECD average, and all, 
including Poland, spend much less than the EU and OECD average in terms of GDP share per unemployed person.

Hence, if the generosity of unemployment benefits has a negative effect on a country's economic performance by reducing worker incentives to find and keep jobs, the countries that should have performed relatively well, ceteris paribus, are Estonia, Czech Republic and Slovakia, while performance should have been hindered in Hungary, Poland and Slovenia. However, as was the case with employment protection policies, the observed GDP growth outcomes in the 1990s (Figure 1) do not correspond to this ranking, thus suggesting that other more important factors have been at play as determinants of GDP growth.

\section{Active Labor Market Policies}

These policies cover many activities, including job search assistance, training of the unemployed and direct job creation. The overall spending as a percentage of GDP by the CEE countries on these policies is below that of the EU countries and is hence closer to that of the US. Within the CEE candidates for EU admission, Riboud et al. (2001) find that both the share of GDP spent on active policies and share of GDP spent on active policies per unemployed person are very low in Estonia and the Czech Republic, while they are relatively high in Slovenia and to a lesser extent in Slovakia, Hungary and Poland. In examining these findings in relationship to Figure 1, it is clear that the relative economic performance of the CEE countries in terms of GDP growth since 1989 has been better in countries with higher expenditures on active labor market policies. This finding is interesting and goes in the right direction - countries that spend more on providing skills, jobs and matching of workers and jobs grow faster. The problem is that micro 
studies in transition economies have had a hard time identifying a positive effect of active labor market policies (Munich, Svejnar and Terrell, 1998). The question for future analytical research is therefore whether the benefits of active labor market policies exceed their costs and whether the net benefits are sizable enough to make a substantial difference in terms of GDP growth.

\section{Trade Unions}

While trade unions in the former Soviet bloc countries have changed from institutions of Communist party control and distributors of fringe benefits to becoming representatives of workers' economic interests, their power, especially in the private sector, appears not to be substantial. Riboud et al. (2001) calculate union density to be about $60 \%$ in Hungary, Slovenia and Slovakia, and much lower in the Czech Republic (43\%), Estonia (36\%) and Poland (34\%). This yields CEE average union density of 49\%, which is somewhat higher than the EU average of $44 \%$ and OECD average of $40 \%$. Union coverage (ability to extend the union contract to non-union workers) is low in the Czech Republic and Estonia, but it is higher in the other four EU admission candidate countries. In the multi-union context of the CEE countries, coordination among various trade unions is low in all the CEE countries except for Slovenia. Overall, the values of the three measures of trade union power - density, coverage and coordination - do not appear to be good predictors of the relative GDP growth of the CEE countries since 1989. Payroll Taxes

The need to control budget deficits during the 1990s has led most transition economies to impose relatively high payroll taxes. By the late 1990s, payroll taxes ranged from 33\% in Estonia, to 38\% in Slovenia, 44\% in Hungary, $47.5 \%$ in the Czech Republic, 
$48 \%$ in Poland, and $50 \%$ in Slovakia. These tax rates are well in excess of the EU average rate of $24 \%$. While wages in the CEE countries were initially so low that the payroll tax rates often did not represent a major burden, the situation changed as real wages grew in the mid and late 1990s. The fact that the two countries with the highest payroll tax rates (Poland and Slovakia) also have the highest unemployment rates points to a possible link between labor cost and (un)employment, a topic that I take up in the next section. However, as with the other measures of relative labor market regulations or institutional rigidities, the relative rate of economic growth of the CEE countries during the 1990s is not related in a simple way to the payroll tax burden.

In concluding this section, let me point out that in Russia and the other countries of the Commonwealth of Independent States, labor market regulations and institutional developments have been weaker than in CEE countries. Moreover, the official unemployment benefits were lower to start with and decreased dramatically in real terms over time -- and some were not paid at all. The relatively poor economic performance of the transition economies further east (see Figure 1) has thus occurred with less rather than more labor market regulation and institutionalization.

\section{Empirical Evidence}

In this section, I provide a selective review of the conclusions that may be drawn from analytical studies of transitional labor markets. This evidence is a useful complement of the review of institutional and regulatory developments in the preceding section. For more in-depth reviews of analytical studies of the transitional labor markets, the reader is referred to Svejnar (1999) and Boeri and Terrell (2002). Employment Adjustment and Wage Setting at the Firm Level 
In most transition economies, the employment decline reached 15-30 percent in the 1990s. A continuous decline was observed in Russia, Slovakia and Romania; an Lshape pattern detected in Bulgaria, Hungary and Slovenia; a U-shape pattern in Poland; and a sideways S-shape pattern in the Czech Republic. When combined with the GDP data in Figure 1, the employment data suggest that restructuring in the transition economies involved an initial decline in labor productivity as output fell faster than employment and a subsequent rise in productivity as output and employment stopped declining. But a note of caution is in order here. With production shifting from large to small firms, the decline in employment (and output) may be less pronounced than suggested by the official data, since small firms are harder to capture in official statistics.

State-owned enterprises in all the transition economies rapidly decreased employment and/or real wages in the early 1990s. In Central Europe, the greatest initial reduction in industrial employment occurred in Hungary (over 20 percent), followed by Slovakia (over 13 percent), Poland (over 10 percent), and the Czech Republic (9 percent). The downward adjustment in industrial wages in the early 1990s proceeded in reverse order and amounted to 24 percent in the Czech Republic, 21 percent in Slovakia and 1 percent in Poland. Hungarian real wages in industry actually rose by 17 percent (Basu, Estrin and Svejnar, 2000). In Russia and the rest of CIS, the adjustment brought a mixture of wage and employment adjustment (Desai and Idson, 2000) and the wage decline was more pronounced than in central and eastern Europe (Boeri and Terrell, 2002). While real wages in Central and East Europe have increased considerably after their initial decline, in Russia and a number of other CIS countries real wages declined until 1993 and stagnated or increased only moderately in the mid-to-late 1990s (Svejnar, 1999; EBRD, 
2000). The trajectory of real incomes has thus been very different in the more and less advanced transition economies.

Basu, Estrin and Svejnar $(1997,2000)$ estimate that labor demand elasticities with respect to output and wages were significant in the more marketized pre-transition economies (Hungary and Poland) and that they rose rapidly in all of Central Europe as the transition was launched. The sharp decline in output at the start of the transition was hence reflected in the labor market, but depending on the institutional setting in a given country, it was absorbed more by employment or wage decreases. The empirical evidence on labor demand hence indicates that the labor markets were quite flexible from early on, but that the flexibility has different manifestations in different countries.

The empirical studies also indicate that, except for Poland, wages were set relatively independently of firms' performance under communism. During the transition, wages started to vary systematically with revenues per worker, suggesting that rent sharing has become a phenomenon in the CEE economies. ${ }^{3}$ Interestingly, evidence from Bulgaria suggests that the compensation of chief executives in not fully state-owned firms is positively related to labor productivity (Jones and Kato, 1997).

Firm ownership and legal form (type of registration and hence corporate governance) are not found to have a simple and uniform effect on employment or wages. In the large samples, covering the early transition period, there appears to be no uniform employment effect, while in the smaller samples that extend further into the transition period, one finds some evidence that privatized firms may at first reduce employment and then increase it faster over time. Finally, foreign ownership appears to be increasing

\footnotetext{
${ }^{3}$ This relationship is not found in some studies, however, when total revenue rather than revenue per worker is used as an explanatory variable.
} 
employment (and output). There is also some evidence that private firms tend to pay higher wages than other firms, but the evidence is not robust and relates only to some countries. Finally, unlike with data on individuals, within firm-level studies there is little evidence that wages are negatively related to local unemployment (wage curve effect). Unemployment

As may be seen from Table 1, within two years after the start of the transition, the unemployment rate rose from zero into double digits in most economies of Central and East Europe. For example, by 1993 the unemployment rate reached 16 percent in Bulgaria and Poland, 12 percent in Hungary and Slovakia, 10 percent in Romania, 9 percent in Slovenia, but only 3.5 percent in the Czech Republic. The high unemployment rates reflected high rates of inflow into unemployment as firms laid off workers, and relatively low outflow rates as the unemployed found it hard to find new jobs. The Czech labor market was an ideal model of a transition labor market, characterized by high inflows as well as outflows, with unemployment representing a transitory state between old and new jobs (Ham, Svejnar and Terrell, 1998, 1999, Svejnar 1999, and Boeri, 2000). Unemployment rose more slowly in the Commonwealth of Independent States and the Baltic countries, as firms were slower to lay off workers and used wage declines and arrears as devices to hold on to workers (Boeri, 2000, and Boeri and Terrell, 2002).

Over time, the patterns of unemployment have shown considerable differentiation. The Czech Republic was the only Central European country to enter recession in the second half of the 1990s and its unemployment rate correspondingly rose to 8 percent. The fast-growing economies of Poland, Hungary, Slovenia, and to a lesser extent Slovakia managed to reduce their high unemployment rates in the late 1990s. 
Conversely, the Commonwealth of Independent States and the Baltic countries experienced gradual increases in unemployment as their transition proceeded. A turning point occurred by 1999-2000 as the unemployment rate rose again in Bulgaria, the Czech Republic, Poland, Slovakia and Slovenia. It stabilized in countries such as Hungary, Romania and Russia. As may be seen from Table 1, with the exception of Hungary, Slovenia and Romania, transition economies have recently had unemployment rates that are at least as high, and often significantly exceed, those observed in the European Union.

In view of the high unemployment rates in all the CEE economies in the early to mid 1990s except for the Czech Republic, the studies of unemployment in these countries have focused on the determinants of outflow from unemployment into employment and on the efficiency of matching of the unemployed and vacancies. A particularly intriguing issue has been the difference in unemployment between the Czech Republic and the counterpart republic of Slovakia (and by implication the other CEE economies). Ham et al.'s $(1998,1999)$ estimates of hazard models suggest that about onethird of the difference between the Czech and Slovak expected unemployment durations is brought about by differences in observable demand conditions, while the remaining two-thirds is brought about by different coefficient of the estimated hazards (proxying for different behavior of individuals, firms and labor market institutions). The second principal finding of the hazard estimates from several countries is that the generosity of the unemployment compensation scheme has only a moderate negative effect on efficiency in terms of lengthening an unemployment spell. Finally, the estimated coefficients on the demographic and demand variables indicate that minorities (e.g., Romanies in the Czech and Slovak Republics or non-Slovenians in Slovenia), 
handicapped, the least educated, and often also the single and the old unemployed workers have a harder time than others obtaining jobs. The estimated effects of gender and marital status vary across countries and specifications. A number of studies find that the probability of moving from unemployment to employment is negatively related to local unemployment rate.

The results of the matching function studies indicate that great care must be taken in collecting, aggregating and adjusting the data, specifying the functional form and selecting the estimating procedure. In particular, there is some evidence that the usual assumptions of a Cobb-Douglas form and constant returns to scale may be rejected when these factors are carefully taken into account. The exceptionally low unemployment rate in the Czech Republic as compared to Slovakia and the other Central and East European economies appears to have been brought about principally by (1) a rapid increase in vacancies along with unemployment in the Czech Republic, resulting in a balanced unemployment-vacancy situation at the aggregate as well as district level, (2) a major part played by vacancies and the newly unemployed in the outflow from unemployment, (3) a matching process with strongly increasing returns to scale throughout (rather than only in parts of) the transition period, and (4) ability to keep the long term unemployed at relatively low levels. The matching function studies hence provide complementary evidence to the hazard estimates in that they identify local demand factors (vacancies) and the efficient behavior of agents and institutions (high returns to scale in matching) as being key to the low unemployment situation in the Czech Republic. Some, but not all, of the studies point to the importance of active labor market policies in increasing the efficiency of matching. 


\section{Job Destruction, Job Creation and Labor Mobility}

The reduction in employment in the old state-owned firms, rise in unemployment and establishment of new firms have brought about considerable destruction and creation of jobs, as well as mobility of labor. Contrary to the main models of the transition process, Jurajda and Terrell (2001) show that job creation in new firms is not necessarily tightly linked to job destruction in the old firms since many new jobs have been created even in economies (such as the Czech Republic) that experienced low rates of job destruction. They also show that in both Czech Republic and Estonia more than one-half of the labor force moved from old to newly created firms within a short period of 4-5 years. Sabirianova (2000) provides a related structural insight, namely that much of the labor mobility consisted of occupational rather than geographic change, with individuals moving from one occupation to another within regions, as jobs in old occupations were destroyed and opportunities in new occupations were created. Compared to the U.S. labor market, where individuals move more geographically than occupationally, the transition is a special phenomenon in that it has led to more occupational than geographic mobility.

\section{Provision of Fringe Benefits}

While data limitations prevent one from drawing strong conclusions about the provision of fringe benefits by firms in CEE countries, the Polish and Czech evidence suggests that benefits are more prevalent in state-owned and privatized firms than in newly established private firms. Moreover, the evidence from the Czech Republic and Romania suggests that firms that have restructured may be exploiting the incentive aspects of fringe benefits. 


\section{Returns to Human Capital}

With the exception of East Germany and to some extent possibly men in Bulgaria, the various studies indicate that returns to education increased during the transition as compared to the pre-transition period. This suggests that education acquired under communism has a higher payoff during the transition but that a rapid introduction of a market economy and western wage scales, as happened in East Germany with the unification, may result in a decrease in the payoff to this human capital. The studies also indicate that women enjoyed a higher rate of return on education than men under communism and that the gap narrowed as the transition started. In several countries, there is evidence that return to experience obtained under communism fell during the transition.

\section{Income Distribution}

The communist countries had highly egalitarian income distributions. In central and east Europe, the Gini coefficients ranged from 20 in Czechoslovakia and Slovenia to 25 in Poland in the late 1980s. The 1988 Ukrainian Gini coefficient of 23 (based on survey data) and the 1991 Russian coefficient of 26 based on the registry wage data of the Russian Statistical Office (Goskomstat) suggest that income distribution was relatively egalitarian in the former Soviet Union as well. However, inequality increased during the 1990s, with the Gini coefficient reaching 26-34 in central and east Europe, 30 in Ukraine and 40 in Russia. These coefficients bring inequality in the transition economies into the range spanned by capitalist economies from the relatively egalitarian Sweden to the relatively inegalitarian United States, and in line with developing countries such as India. However, while the central and east European data seem to reflect reality, the Russian 
and Ukrainian data may well understate the extent of inequality. In particular, the Goskomstat data are based on wages that firms are supposed to be paying to workers, but many Russian firms have not been paying contractual wages (Desai and Idson, 2000). Inequality measures based on survey data from the Russian and Ukrainian Longitudinal Monitoring of households suggest that income inequality in Russia and Ukraine has reached much higher levels - a Gini coefficient of 47-50 - which resembles the level of inequality found in developing economies with relatively inegalitarian distribution of income. The egalitarian structure of income distribution in central and eastern European countries has been brought about by their social safety nets, which rolled back inequality that would have been brought about by market forces alone (Garner and Terrell, 1998). Conversely, the Russian social safety net has been regressive -- it has made the distribution of income more unequal than it would have been without it (Commander, Tolstopiatenko and Yemtsov, 1999).

Overall, the income distribution data indicate that the regulatory and institutional frameworks of the transition economies have been flexible enough to give rise to wider income differentials. In Central and East Europe, the governments used social transfers to cushion the impact of market forces and reduce extreme inequalities in income and consumption.

\section{Concluding Observations}

Since 1989, most transition economies have experienced a period of sharp economic decline followed by slower than expected economic growth, a rise of the unemployment rate from zero to double digits, and appearance of a high share of long-term unemployed. These developments have naturally raised concerns that insufficient labor market 
flexibility is an important factor causing these economic problems. My conclusion, based on the evidence reviewed in this paper, is that labor market flexibility is an issue but that it is not a major factor in comparison to imperfections and regulations in other areas (not explored in this paper) such as the housing markets, transportation infrastructure, capital markets, corporate governance, legal framework, and business environment.

At some level of abstraction, high unemployment rate is obviously a manifestation of labor market imperfections. For example, in a simple spot labor market there should be a low enough wage at which the market clears and observed unemployment is frictional. Bulgaria, Poland and Slovakia, with 2001 unemployment rates of $15-20 \%$, are obviously above the frictional level of unemployment, as are arguably most other transition economies. However, the spot market model, while useful as a yardstick, misses important real-world phenomena even when minimum wages are very low. From a policy standpoint, it is therefore useful to ask whether labor markets in the transition economies perform worse than those in functioning market economies.

My assessment is that transition labor markets have been as flexible and functional as labor markets in the market economies and that the observed differences across transitional labor markets do not account for cross-country differences in economic performance. My conclusion is based on the following points:

1. The extent and effects of employment protection, labor market policies and unionization in the transition economies are similar to OECD and EU averages, and on some measures they resemble OECD economies with the most flexible labor markets. 
2. The transition economies with the least regulated and institutionally least rigid labor markets have not been uniformly the fastest growing ones and vice versa.

3. Estimated labor demand elasticities quickly rose to western levels, indicating that firms started adjusting employment to output demand and wage shocks.

4. Substantial labor mobility took place from the old to the new firms, with some countries transferring over one-half of the labor force within four to five years.

5. Labor mobility appears to have been rational in that it has involved both quits and layoffs, with the resulting wage gains being higher on average for the quitters than the displaced workers. Workers have reacted to labor demand shocks by traditional as well as less-traditional (in the western context) responses, including massive occupational mobility.

6. The return to education and other forms of human capital have risen substantially and wages began to play an equilibrating role.

From the policy standpoint, there are several important findings. First, the generosity of unemployment benefits has been found to have only modest negative effect on efficiency in terms of extending unemployment spells. This provides policy makers with latitude in setting the parameters of the compensation system so as to ensure popular support for the completion of the transition process. Second, economies with high unemployment tend to have fewer vacancies and estimated parameters that show lower efficiency of matching between the unemployed and vacancies and lower probability (hazard) of the unemployed leaving unemployment for employment. The lack of vacancies points to low demand as a cause of unemployment, while the matching and hazard estimates suggest that these economies suffer from structural issues such as skill 
mismatch, inferior functioning of labor market institutions and active labor market policies, and less flexible behavior of employers and workers. Third, there are indications of rent-sharing by workers, which may signal the presence of an insider-outsider problem.

The above findings suggest that the principal reasons for the rapid but uneven rise in unemployment and the share of long-term unemployed in transition economies in the 1990s were (a) the enormous extent of transition-related restructuring, with labor demand falling dramatically in existing firms, (b) a major skill mismatch that took varying periods of time to alleviate, and (c) varying degrees of imperfections and regulations in other areas such as the housing markets, transportation infrastructure, capital markets, corporate governance, legal framework, and business environment.

The outstanding issue, however, is why there has been a significant resurgence of unemployment in some of the growing economies (Bulgaria, Poland, and Slovakia) but not in others in the very late 1990s and early 2000s. These are presumably not brought about by sudden bouts of transition-related restructuring, skill mismatch and newly created imperfections outside of the labor market. Demographic forces (especially a recent baby boom-let) account for some of these developments, but further research is needed to clarify this issue. 


\section{References}

Basu, Swati, Saul Estrin and Jan Svejnar (1997), "Employment and wage behaviour of industrial enterprises in transition economies: The cases of Poland and Czechoslovakia," Economics of Transition, 5(2), 271-187.

Basu, Swati, Saul Estrin and Jan Svejnar (2000), "Employment and Wages in Enterprises under Communism and in Transition: Evidence from Central Europe and Russia," The William Davidson Institute Working Papers, No.114b (1995, revised 2000).

Boeri, Tito, Structural Change, Welfare Systems and Labor Allocation, Oxford: Oxford University Press 2000.

Boeri, Tito and Katherine Terrell, "Institutional Determinants of Labor Reallocation in Transition", Journal of Economic Perspectives, Feb. 2002, Vol. 16, No. 2.

Commander, Simon, Andrei Tolstopiatenko and Ruslan Yemtsov, "Channels of redistribution: Inequality and poverty in the Russian transition," Economics of Transition, 7(1), 1999, 411-465.

Desai, Padma and Todd Idson, Work without Wages: Russia's Nonpayment Crisis, Cambridge, MA: MIT Press, 2000.

EBRD, Transition Report, London: European Bank for Reconstruction and Development, 1996 - 2001.

Garner, Thesia and Katherine Terrell, "A Gini Decompositon Analysis of Inequality in the Czech and Slovak Republics During the Transition," The Economics of Transition, 1998, Vol. 6, No. 1, 23-46.

Gomulka, "Obstacles to recovery in Transition Economies," in P. Aghion and N. Stern (eds.), Obstacles to Enterprise Restructuring in Transition, 1994, EBRD Working Paper, No 16.

Ham, John, Jan Svejnar and Katherine Terrell, "Women's Unemployment During the Transition: Evidence from Czech and Slovak Micro Data," Economics of Transition, 1999, Vol.7, No. 1, 47-78.

Ham, John, Jan Svejnar and Katherine Terrell, "Unemployment and the Social Safety Net During Transitions to a Market Economy: Evidence from the Czech and Slovak Republics, American Economic Review, December 1998, Vol. 88, No. 5, pp. 1117-1142.

Jones, Derek C., and Kato, Takao (1997), "The Nature and the Determinants of Labor Market Transitions in Former Communist Economies: Evidence from Bulgaria", Industrial Relations, 36(2):229-254. 
Jurajda, Stepan and Katherine Terrell, "Optimal Speed of Transition: Micro Evidence from the Czech Republic and Estonia," Working Paper No. 355, William Davidson Institute, Revised 2001.

Munich, Daniel, Jan Svejnar and Katherine Terrell, "Worker-Firm Matching in Transition Economies," William Davidson Institute Working Paper No. 107, University of Michigan Business School, 1998.

Riboud, Michelle, Carolina Sanchez-Paramo and Carlos Silva-Jauregui, "Does Eurosclerosis Matter? Institutional Reform and Labor Market Performance in Central and Eastern European Countries in the 1990s."World Bank working Paper No. 591, 2002.

Sabirianova, Klara, "The Great Human Capital Reallocation: An Empirical Analysis of Occupational Mobility in Transitional Russia," Working Paper No. 309, The William Davidson Institute, October 2000.

Svejnar, Jan, "Pensions in the Former Soviet Bloc: Problems and Solutions," in Council on Foreign Relations, The Coming Global Pension Crisis, New York, 1977.

, "Labor Markets in the Transitional Central and East European Economies," Chapter 42 in Orley Ashenfelter and David Card (eds.), Handbook of Labor Economics, North Holland, Vol. 3B, 1999.

, "The Performance and Challenges in Transition Economies," Journal of Economic Perspectives, February 2002. 


\section{Table 1}

Unemployment Rate

(Percent)

\begin{tabular}{|c|c|c|c|c|c|c|c|c|c|c|c|c|}
\hline & 1990 & 1991 & 1992 & 1993 & 1994 & 1995 & 1996 & 1997 & 1998 & 1999 & 2000 & $2001^{*}$ \\
\hline Czech Republic & 0.7 & 4.1 & 2.6 & 3.5 & 3.2 & 2.9 & 3.5 & 5.2 & 7.5 & 9.4 & 8.9 & 8.2 \\
\hline Hungary & 1.7 & 8.5 & 9.8 & 11.9 & 10.7 & 10.2 & 9.9 & 8.7 & 7.8 & 7.0 & 6.5 & 5.7 \\
\hline Poland & 6.5 & 11.8 & 13.6 & 16.4 & 16.0 & 14.9 & 13.2 & 8.6 & 10.4 & 13.0 & 16.1 & 18.2 \\
\hline Slovak Republic & 1.5 & 6.6 & 11.4 & 14.4 & 14.6 & 13.1 & 12.8 & 12.5 & 15.6 & 19.2 & 17.9 & 18.3 \\
\hline Slovenia & 4.7 & 8.2 & 11.6 & 9.1 & 9.1 & 7.4 & 7.3 & 7.1 & 7.6 & 7.4 & 7.0 & 6.4 \\
\hline Estonia & 0.6 & 1.5 & 3.7 & 6.5 & 7.6 & 9.7 & 10.0 & 9.7 & 9.6 & 10.3 & 13.6 & 12.6 \\
\hline Bulgaria & 1.7 & 11.1 & 15.3 & 16.4 & 12.8 & 11.1 & 12.5 & 13.7 & 12.2 & 16.0 & 16.9 & 19.8 \\
\hline Romania & na & 3.0 & 8.2 & 10.4 & 8.2 & 8.0 & 6.7 & 6.0 & 6.3 & 11.5 & 7.1 & 6.5 \\
\hline Russian & na & 0.1 & 5.2 & 5.9 & 8.1 & 9.5 & 9.7 & 11.8 & 13.3 & 11.7 & 10.4 & 9.7 \\
\hline Ukraine & na & na & 0.3 & 0.3 & 0.4 & 0.5 & 1.5 & 2.7 & 4.3 & 5.4 & 5.3 & 3.0 \\
\hline United States & 5.6 & 6.8 & 7.5 & 6.9 & 6.1 & 5.6 & 5.4 & 4.9 & 4.5 & 4.2 & 4.0 & 4.8 \\
\hline
\end{tabular}

Sources: William Davidson Institute based on EBRD Transition Report Update 2002, Datastream-EIU, and WDI staff calculations. 
Figure 1

Real GDP Index

(1989 Base Year)

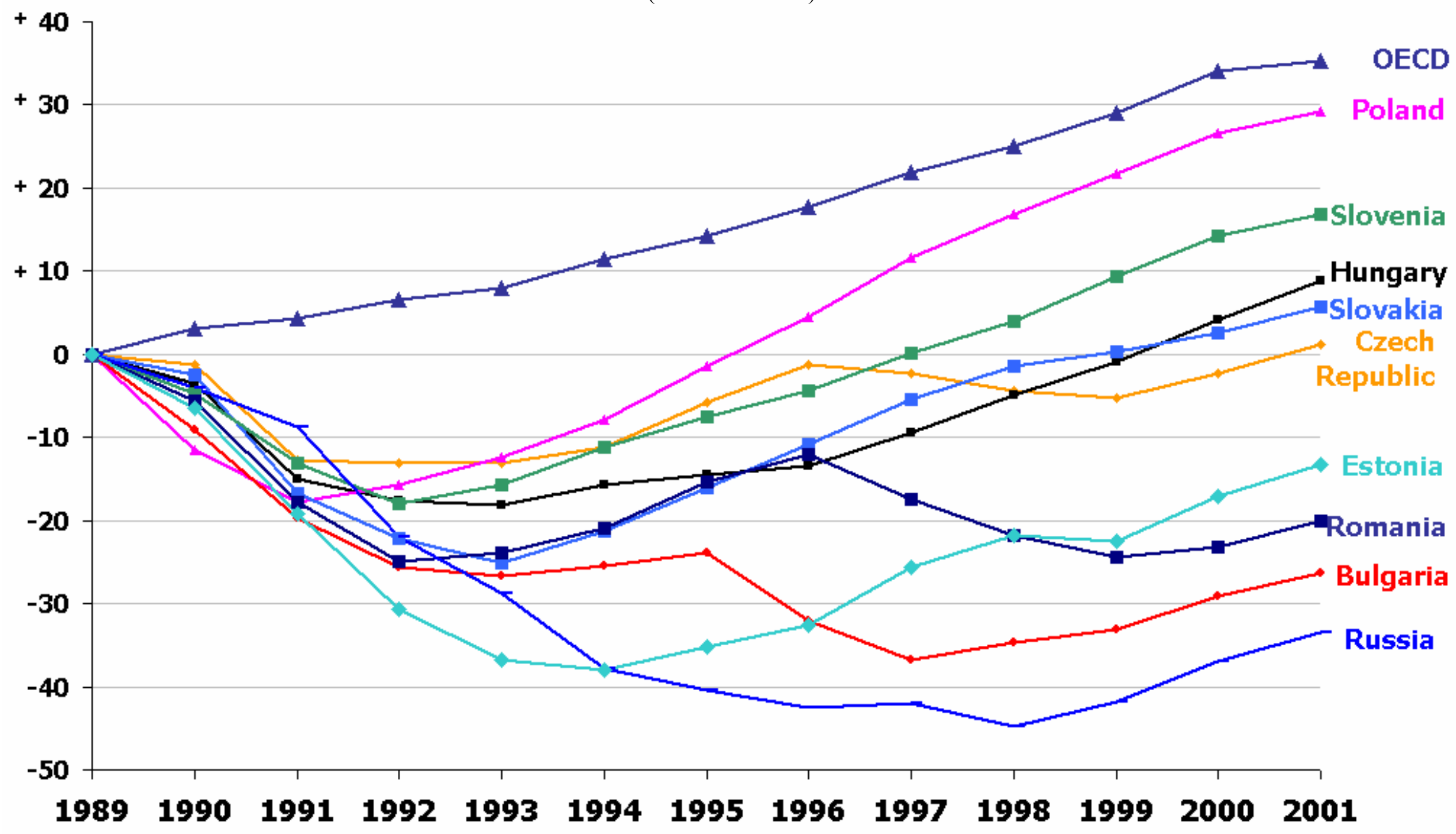

Sources: William Davidson Institute based on various EBRD Transition Reports, OECD Economic Outlook Vol. 71 June 2002, and staff calculations. 


\section{DAVIDSON INSTITUTE WORKING PAPER SERIES - Most Recent Papers}

The entire Working Paper Series may be downloaded free of charge at: www.wdi.bus.umich.edu

CURRENT AS OF 9/16/02

\begin{tabular}{|c|c|c|}
\hline Publication & Authors & Date \\
\hline No. 496: Labor Market Flexibility in Central and East Europe & Jan Svejnar & Aug. 2002 \\
\hline $\begin{array}{l}\text { No. 495: When Information Dominates Comparison: A Panel Data } \\
\text { Analysis Using Russian Subjective Data }\end{array}$ & Claudia Senik & May 2002 \\
\hline No. 494: Corruption and Cross-Border Investment: Firm Level Evidence & $\begin{array}{l}\text { Beata K. Smarzynska and Shang- } \\
\text { Jin Wei }\end{array}$ & Aug. 2002 \\
\hline $\begin{array}{l}\text { No. 493: Modeling Sequences of Long Memory Positive Weakly } \\
\text { Stationary Random Variables }\end{array}$ & Dmitri Koulikov & Aug. 2002 \\
\hline $\begin{array}{l}\text { No. 492: Effects of Ownership and Financial Status on Corporate } \\
\text { Environmental Performance }\end{array}$ & $\begin{array}{l}\text { Dietrich Earnhart and Lubomír } \\
\text { Lízal }\end{array}$ & Aug. 2002 \\
\hline $\begin{array}{l}\text { No. 491: Does Economic Uncertainty Have an Impact on Decisions to } \\
\text { Bear Children? Evidence from Eastern Germany }\end{array}$ & $\begin{array}{l}\text { Sumon Kumar Bhaumik and } \\
\text { Jeffrey B. Nugent }\end{array}$ & July 2002 \\
\hline $\begin{array}{l}\text { No. 490: The Reallocation of Workers and Jobs in Russian Industry: } \\
\text { New Evidence on Measures and Determinants }\end{array}$ & J. David Brown and John S. Earle & Aug. 2002 \\
\hline $\begin{array}{l}\text { No. 489: The Incidence and Cost of Job Loss in a Transition Economy: } \\
\text { Displaced Workers in Estonia, 1989-1999 }\end{array}$ & $\begin{array}{l}\text { Hartmut Lehmann, Kaia Phillips } \\
\text { and Jonathan Wadsworth }\end{array}$ & Aug. 2002 \\
\hline No. 488: Integration: An Empirical Assessment of Russia & $\begin{array}{l}\text { Daniel Berkowitz and David N. } \\
\text { DeJong }\end{array}$ & Feb. 2002 \\
\hline $\begin{array}{l}\text { No. 487: Dual Inflation under the Currency Board: The challenges of } \\
\text { Bulgarian EU accession }\end{array}$ & $\begin{array}{l}\text { Nikolay Nenovsky and Kalina } \\
\text { Dimitrova }\end{array}$ & July 2002 \\
\hline $\begin{array}{l}\text { No. 486: Worker Flows, Job Flows and Firm Wage Policies: } \\
\text { An Analysis of Slovenia }\end{array}$ & $\begin{array}{l}\text { John Haltiwanger and Milan } \\
\text { Vodopivec }\end{array}$ & July 2002 \\
\hline $\begin{array}{l}\text { No. 485: Do Schumpeterian Waves of Creative Destruction Lead to } \\
\text { Higher Productivity? Panel Data Evidence from Poland }\end{array}$ & Frederic Warzynski & July 2002 \\
\hline $\begin{array}{l}\text { No. 484: Labor Market Institutions and Restructuring: Evidence from } \\
\text { Regulated and Unregulated Labor Markets in Brazil }\end{array}$ & Jasper Hoek & July 2002 \\
\hline $\begin{array}{l}\text { No. 483: The Balassa-Samuelson effect in Central and Eastern Europe: } \\
\text { Myth or reality? }\end{array}$ & $\begin{array}{l}\text { Balázs Égert, Imed Drine, Kirsten } \\
\text { Lommatzsch and Christophe } \\
\text { Rault }\end{array}$ & July 2002 \\
\hline No. 482: Real Exchange Rates in Transition Economies & Boštjan Jazbec & July 2002 \\
\hline $\begin{array}{l}\text { No. 481: Labor Force Participation Dynamics in the Romanian Labor } \\
\text { Market }\end{array}$ & Alexandru Voicu & July 2002 \\
\hline $\begin{array}{l}\text { No. 480: Equilibrium Real Exchange Rates in Central Europe's } \\
\text { Transition Economies: Knocking on Heaven's Door }\end{array}$ & Balázs Égert & July 2002 \\
\hline $\begin{array}{l}\text { No. 479: The Impact of Minimum Wages on Wage Inequality and } \\
\text { Employment in the Formal and Informal Sector in Costa Rica }\end{array}$ & $\begin{array}{l}\text { Fatma El-Hamidi and Katherine } \\
\text { Terrell }\end{array}$ & Apr. 2001 \\
\hline $\begin{array}{l}\text { No. 478: Beyond Oaxaca -Blinder: Accounting for Differences in } \\
\text { Household Income Distributions }\end{array}$ & $\begin{array}{l}\text { François Bourguignon, Francisco } \\
\text { H. G. Ferreira and Phillippe G. } \\
\text { Leite }\end{array}$ & Feb. 2002 \\
\hline $\begin{array}{l}\text { No. 477: Participation Behavior of East German Women after German } \\
\text { Unification }\end{array}$ & Holger Bonin and Rob Euwals & July 2002 \\
\hline No. 476: Duration and Risk of Unemployment in Argentina & $\begin{array}{l}\text { Sebastian Galiani and Hugo A. } \\
\text { Hopenhayn }\end{array}$ & Oct. 2001 \\
\hline $\begin{array}{l}\text { No. 475: After, Before and During: Returns to Education in the } \\
\text { Hungarian Transition }\end{array}$ & $\begin{array}{l}\text { Nauro F. Campos and Dean } \\
\text { Jolliffe }\end{array}$ & Apr. 2002 \\
\hline No. 474: The Locking-in Effect of Subsidized Jobs & Jan C. van Ours & June 2002 \\
\hline No. 473: How Reform Worked in China & Yingyi Qian & June 2002 \\
\hline No. 472: An Economic Perspective on Russia's Accession to the WTO & Robert M. Stern & June2002 \\
\hline $\begin{array}{l}\text { No. 471: The Effects of Ownership Forms and Concentration on Firm } \\
\text { Performance after Large-Scale Privatization }\end{array}$ & Evzen Kocenda and Jan Svejnar & May 2002 \\
\hline
\end{tabular}

